\title{
PERMASALAHAN YANG DIHADAPI PEDAGANG KAKI LIMA PASCA RELOKASI DI SENTRA PKL JALAN BENTENG PANCASILA KOTA MOJOKERTO
}

\author{
Rizky Prigionila \\ Program Studi Pendidikan Ekonomi, Jurusan Pendidikan Ekonomi, Fakultas Ekonomi \\ Universitas Negeri Surabaya, e-mail : rizkyprigionila@mhs.unesa.ac.id

\section{Lucky Rachmawati} \\ Program Studi Ekonomi, Jurusan Ilmu Ekonomi, Fakultas Ekonomi Universitas Negeri Surabaya, \\ e-mail : luckyrachmawati@unesa.ac.id
}

\begin{abstract}
Abstrak
Program relokasi dilakukan oleh pemerintah sudah berjalan sesuai dengan rencana. Namun saat ini jumlah PKL berkurang disebabkan masih banyaknya permasalahan yang dihadapi oleh para pedagang sejak awal menempati sentra PKL Jalan Benteng Pancasila. Berdasarkan hal tersebut, maka penulis ingin meneliti tentang permasalahan yang dihadapi pedagang kaki lima pasca relokasi dan upaya yang dilakukan pedagang dalam mengatasi permasalahan tersebut dalam meningkatkan pendapatan pedagang kaki lima jalan Benteng Pancasila kota Mojokerto dengan tujuan (1) untuk menjelaskan permasalahan yang dihadapi pedagang kaki lima pasca relokasi di Sentra PKL jalan Benteng Pancasila kota Mojokerto, (2) untuk menjelaskan upaya yang dilakukan pedagang kaki lima dalam menghadapi permasalahan yang ada serta dalam peningkatan pendapatan di Sentra PKL jalan Benteng Pancasila kota Mojokerto. Jenis penelitian ini adalah penelitian deskriptif. Subjek penelitian ini adalah pedagang kaki lima di sentra PKL jalan Benteng Pancasila sebanyak 10 informan. Penentuan informan dalam penelitian ini menggunakan teknik snowball sampling. Analisa data terdiri dari reduksi data, penyajian data, menarik kesimpulan atau verifikasi. Hasil penelitian menunjukkan bahwa permasalahan yang dihadapi pedagang kaki lima pasca relokasi adalah pemasaran, permodalan, sarana prasarana, kurangnya dukungan pemerintah dan teknologi. Permasalahan tersebut berpengaruh terhadap tingkat pendapatan yang diperoleh pedagang. Upaya dari pedagang dalam menghadapi permasalahan yang ada adalah meningkatkan pelayanan dan bekerja sama dengan para pedagang, berjualan di lokasi lain dan mengganti jenis barang dagangan.
\end{abstract}

Kata Kunci: Relokasi, Pedagang Kaki Lima, Pendapatan.

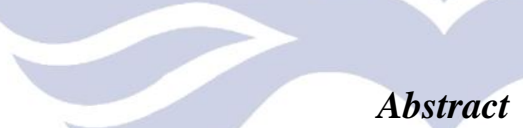

The relocation program carried out by the government has gone according to plan. But now the number of street vendors is decreasing because there are still many problems faced by traders since the beginning of occupying the center of street vendors in the Pancasila Fortress. Based on this, the authors want to examine the problem faced by street vendors after relocation and efforts made by traders in overcoming these problems in increasing the income of street vendors at the Pancasila Fortress in the city of Mojokerto with the aim of (1) to explain the problems faced by street vendors after relocation in the center of the street at the Pancasila Fortress in the city of Mojokerto, (2) to explain the efforts made by street vendors in dealing with existing problems and in increasing revenue in the center of the street at the Pancasila Fortress in the city of Mojokerto. This type of research is a descriptive study with a qualitative approach. The subjects of this study were street vendors who were in the PKL center on Pancasila Fortress as many as 10 informants. Determination of informants using the snowbal sampling technique. Data analysis consists of data reduction, data presentation, drawing conclusions or verification. The results showed that the problems faced by street vendors after relocation were marketing, capital, infrastructure, lack of government support and technology. These problems greatly influence the level of income obtained by traders. Efforts made by traders in dealing with existing problems are to improve service and cooperate with traders, selling in other locations and replacing types of merchandise.

Keywords: Relocation, Street Vendor, Income. 


\section{PENDAHULUAN}

Indonesia merupakan salah satu negara yang dalam kategori Negara berkembang, yang menyadari akan pentingnya pembangunan untuk mewujudkan kesejahteraan bangsa. Pembangunan nasional terutama dalam bidang ekonomi merupakan hal mutlak yang harus dilaksanakan jika suatu bangsa akan meningkatkan taraf hidup serta kesejahteraan masyarakatnya.

Proses pembangunan ekonomi, tentunya tidak akan luput dari berbagai permasalahan terkait Pedagang Kaki Lima (PKL). Pedagang kaki lima merupakan bagian yang tidak dapat dipisahkan dari sistem ekonomi Indonesia. Permasalahan mengenai PKL ini selalu menjadi masalah di berbagai kota di Indonesia. Tidak terkecuali Kota Mojokerto. Adanya PKL tersebut sering menimbulkan permasalahan bagi pemerintah kota manakala mereka menempati ruang public demi kepentingan ekonomi tanpa melihat aturan ketertiban. Sehingga dampak yang ditimbulkan antara lain adalah lalu lintas yang macet, ketertiban umum berkurang, mengganggu keindahan wajah kota hingga sosial ekonomi yang rawan.

Kawasan Alun-alun merupakan kawasan pusat kota kebanggaan warga kota Mojokerto sebagai tempat berkumpulnya warga asli kota Mojokerto maupun dari daerah lain. Selain itu kawasan ini merupakan salah satu pusat perdagangan di kota Mojokerto. Aktivitas perdagangan yang cukup tinggi dikawasan sekitar alunalun kota Mojokerto berdampak pada banyaknya pedagang kaki lima yang tidak tertampung di lokasi yang ditetapkan, misalnya di trotoar dan bahu jalan. Melihat kondisi tatanan dari pedagang kaki lima yang ada di kawasan alun-alun kota yang tidak teratur membuat tata kota menjadi tidak rapi. Hal ini membuat Pemerintah kota Mojokerto mengeluarkan suatu kebijakan dalam rangka penertiban PKL di kawasan tersebut yaitu relokasi PKL.

Penataan PKL di kota Mojokerto ini diatur dalam sumber hukum yaitu Peraturan Daerah Nomor 5 tahun 2005 tentang Penataan dan Pembinaan Kegiatan PKL. Pada tahun 2012 Pemerintah Mojokerto melakukan relokasi untuk PKL di kawasan Alun-alun kota. Penataan ini dilakukan karena kawasan alun-alun kota Mojokerto akan ditata ulang serta dijadikan taman yang bernuansa kerajaan dan fasilitas umum bagi warga. PKL pada daerah tersebut direlokasi dan ditempatkan di Sentra PKL yang berada di jalan Benteng Pancasila kota Mojokerto. Sesuai dengan rencana pemerintah kota Mojokerto telah menyediakan lahan dan kemudian dibangunkan kios permanen untuk ditempati oleh pedagang. Lokasi ini diharapkan dapat barmanfaaat bagi perkembangan perekonomian daerah, utamanya dalam mewujudkan kesejahteraan masyarakat di kota Mojokerto. Dan dengan adanya Sentra PKL ini juga diharapkan mampu menarik lebih banyak orang untuk berbelanja dengan kenyamanan dan pelayanan yang baik, sehingga nantinya akan berdampak pula pada pendapatan pedagang yang diharapkan akan semakin meningkat.

Meskipun program relokasi telah berjalan sesuai dengan rencana, akan tetapi dalam pelaksanaannya masih terdapat berbagai permasalahan. Berdasarkan hasil wawancara yang dilakukan oleh peneliti, dari data awal yang tercatat, jumlah PKL awal yang telah direlokasi adalah 236 PKL. Tetapi saat ini jumlahnya berkurang tinggal 192 PKL. Beberapa permasalahan yang dihadapi diantaranya adalah sepi nya pelanggan atau pengunjung yang datang di lokasi baru. Sehingga para pedagang mengalami penurunan pendapatan.

Selain itu, saat peresmian tempat yang baru, tempat yang dulu dijanjikan satu kios untuk satu pedagang ternyata tidak dapat terealisasi karena kios yang dibangun dengan jumlah pedagang yang ada tidak sesuai. Jumlah pedagang yang di data ternyata lebih banyak daripada jumlah kios yang telah dibangun. Sehingga di dalam satu kios harus di tempati dua hingga tiga pedagang, sehingga sangat berdesak desakan. Pengunjung juga merasa tidak leluasa saat ingin melihat barang yang ingin dibeli.

Tujuan penelitian ini adalah untuk menjelaskan permasalahan yang dihadapi pedagang pasca relokasi di Sentra PKL jalan Benteng Pancasila kota Mojokerto dan upaya yang dilakukan pedagang saat menghadapi permasalahan yang ada serta untuk peningkatan pendapatan pedagang di Sentra PKL jalan Benteng Pancasila.

Tambunan, (2003) menyatakan bahwa pendapatan adalah pembayaran yang di peroleh karena bekerja atau menjual barang dalam waktu tertentu. Dan dari (Sukirno, 2012) perhitungan pendapatan melalui tiga cara yaitu Pertama, cara pengeluaran yaitu dengan cara menjumlahkan nilai pengeluaran atau belanja ke atas barang-barang dan jasa. Kedua, dengan cara produksi yaitu dengan menjumlahkan nilai barang jasa yang diperoleh. Ketiga, yaitu dengan cara pendapatan yang diperoleh dengan cara mengkalkulasi seluruh penermaan pendapatan.

Syamsir, (2011) Pedagang Kaki Lima yaitu pedagang yang melakukan usaha perdagangan informal menggunakan lahan terbuka atau tertutup, sebagian fasilitas umum yang ditentukan oleh Pemerintah sebagai tempat kegiatan usahanya baik dengan menggunakan peralatan bergerak maupun bongkar pasang sesuai waktu yang ditentukan.

Dalam Peraturan Menteri Dalam Negeri Republik Indonesia Nomor 41 Tahun 2012 pengertian Penataan PKL yaitu upaya yang dilakukan oleh pemerintah melalui penetapan lokasi binaan untuk melakukan penetapan, pemindahan, penertiban dan penghapusan lokasi PKL dengan memperhatikan kepentingan umum, sosial, estetika, kesehatan, ekonomi, keamanan, ketertiban, kebersihan lingkungan dan sesuai dengan peraturan perundang-undangan.

Sukirno,(2012) pendapatan adalah jumlah penghasilan yang diterima oleh penduduk atas prestasi kerjanya selama satu periode tertentu, baik harian, mingguan, bulanan ataupun tahunan.

Pribadi \& Mundung, (2007) konsep pemasaran yaitu upaya pemasaran yang memfokuskan dan berorientasi pada konsumen untuk memberikan kepuasan pada konsumen sebagai kunci mencapai tujuan perusahaan. Dalam konsep pemasaran mengandung tiga unsur pokok yaitu (1) mengarahkan usaha kepada pelayanan keperluan kkonsumen yang dilayani. (2) Melaksanakan kegiatan 
pemaaran yang terpadu dalam usaaha memppengaruhi pasar untuk merebut konsumen. (3) Mewujudkan kepuaan konsumen dalaam upaya menciptakan pelanggan tetap.

Burhan(2015) menjelaskan konsep pemasaran dengan istilah marketing mix $7 p$ tentang lokasi yang merupakan tempat adalah dimana suatu produk tersebut di jual yang dapat memudahkan masyarakat untuk mendapatkan produk yang diinginkan. Dalam penentuan lokasi, pengusaha harus memperhatikan aspek seperti tempat produk harus bisa dijangkau oleh konsumen dan tempat produk harus sesuai dengan segmentasi yang dituju.

\section{METODE}

Jenis penelitian ini adalah deskriptif kualitatif. Dalam penelitian deskripstif, ditujukan untuk memeriksa gejalagejala, fakta, atau kejadian secara sistematis dan akurat, mengenai sifat-sifat populasi daerah tertentu. Menganalisis data dengan cara mendiskripsikan atau menggambarkan kumpulan data sebagaimana adanya tanpa ada maksud membikin kesimpulan yang berlaku umum maupun generalisasi.

Selain itu penelitian ini juga digunakan untuk menghasilkan data yang mendalam serta mendapatkan gambaran secara menyeluruh, khususnya tentang kondisi pedagang kaki lima di kawasan jalan Benteng Pancasila kota Mojokerto pasca relokasi.

Objek dalam penelitian kualitatif dinamakan situasi sosial meliputi aspek tempat, aspek pelaku, dan aspek aktivitas. Objek dalam penelitian ini adalah Ketua Paguyuban Sentra PKL jalan Benteng Pancasila, Kepala Seksi Bidang Perdagangan DISPERINDAG kota Mojokerto dan para pedagang. Sedangkan informan penelitian ini yaitu para pedagang yang dianggap paling mampu memberikan berbagai informasi mengenai permasalahan pasca relokasi di Sentra PKL jalan Benteng Pancasila kota Mojokerto.

Dalam pengumpulan data, peneliti menerapkan teknik observasi informan dengan mengamati subyek penelitian secara langsung dengan menggunakan seluruh alat indera. Wawancara mendalam dilakukan secara langsung dengan tatap muka dengan informan bermaksud mendapat gambaran tentang topic yang diteliti. Dokumentasi dilakukan untuk memperoleh data sekunder, dengan mengumpulkan dan mempelajari data serta dokume yang terkait dengan masalah penelitian.

Teknik analisis data dilaksanakan saat berlangsungnya pengumpulan data, serta setelah selesai pengumpulan data dalam periode tertentu. Penggumpulan data dapat dilakukan dengan tiga alur kegiatan, yaitu reduksi data, penyajian data, dan penarikan kesimpulan atau verifikasi. Reduksi data yaitu merangkum, memilih hal yang pokok, memfokuskan pada hal yang penting, diambil tema serta polanya dan membuang yang tidak perlu. Penyajian data dilakukan dengan menyederhanakan hasil informasi komplek yang telah didapatkan dari lapangan ke dalam bentuk sederhana. Penarikan kesimpulan atau verifikasi yaitu menarik kesimpulan selama penelitian berlangsung serta selalu dicek lagi untuk mendapatkan verifikasi yang valid.

Untuk uji keabsahan dalam penelitian ini meliputi uji kredibilitas, uji transferbilitas dan dependenbilitas. Supaya penelitian ini memiliki tingkat kredibilitas tinggi sesuai fakta lapangan, maka upaya yang dilakukan diantaranya adalah melakukan perpanjangan pengamatan, ketekunan ditingkatkan, melakukan triangulasi, serta bahan referensi.

Uji Transferbilitas ini dilakukan dengan bantuan atau teman sejawat untuk melihat hasil penelitian atau abstraksinya serta dimintai tanggapan. Dari tanggapan tersebut diperoleh masukan sejauh mana hasil penelitian mampu dipahami oleh pembaca.

Uji Dependebilitas yaitu dilakukan audit terhadap keseluruhan proses penelitian. Caranya dilakukan oleh auditor, atau pembimbing untuk mengaudit keseluruhan aktivitas peneliti, agar temuan penelitian dapat dipertahankan dan dipertanggungjawabkan secara ilmiah.

\section{HASIL DAN PEMBAHASAN}

Permasalahan Yang Dihadapi Pedagang Kaki Lima Pasca Relokasi

Meskipun program relokasi telah berjalan sesuai rencana, akan tapi pelaksanaannya terdapat berbagai permasalahan. Tidak lama setelah direlokasi ke tempat baru, pedagang yang berada di sentra PKL jalan Benteng Pancasila semakin berkurang jumlahnya dari jumlah awal yaitu 236 PKL menjadi 192 PKL. Penurunan jumlah pedagang ini dikarenakan terdapat beberapa permasalahan yang dihadapi pedagang pasca relokasi. Permasalahan yang dihadapi pedagang kaki lima pada saat setelah direlokasi, adalah :

Pertama, masalah pemasaran. Permasalahan pemasaran disebabkan oleh minimnya jumlah pengunjung, minimnya jumlah pengunjung ini dikarenakan karena belum banyak masyarakat Mojokerto yang mengetahui lokasi baru PKL yang direlokasi yaitu di sentra PKL jalan Benteng Pancasila kota Mojokerto. Sehingga menyebabkan lokasi baru para pedagang ini sepi dan berdampak pada tingkat pendapatan mereka. Selain itu, permasalahan pemasaran ini juga disebabkan karena lokasi yang baru berbeda dengan lokasi yang ditempati oleh para PKL sebelumnya yaitu di alun-alun Mojokerto. Jika di alun-alun Mojokerto lokasinya lebih mengarah ke tempat hiburan. maka di jalan Benteng Pancasila lokasinya lebih mengarah ke hanya sekedar pasar atau pusat perdagangan saja. Hal ini menyebabkn danya perbedaan tingkat jumlah pengunjung yang ada. Sehingga berpengaruh pada pemasaran usaha para pedagang. 
Hal ini sesuai dengan teori oleh Pribadi \& Mundung, (2007) bahwa konsep pemasaran mengandung tiga unsur pokok yaitu mengarahkan usaha pada pelayanan keperluan konsumen yang dilayani, melaksanakan kegiatan pemasaran yang terpadu dalam usaha mempengaruhi pasar agar merebut konsumen, membentuk kepuasan konsumen dalam upaya menciptakan pelanggan tetap. Selain itu, Burhan, (2015) juga menjelaskan konsep pemasaran yang disebut dengan istilah Marketing mix 7p salah satunya adalah place atau bisa disebut dengan lokasi. Pemilihan lokasi merupakan hal yang cukup penting yang harus dilakukan oleh pengusaha. Karena hal ini berkaitan dengan dimana suatu produk tersebut dijual yang dapat memudahkan masyarakat untuk mendapatkan produk yang diinginkan.lokasi harus bisa dijangkau oleh konsumen dan lokasi harus sesuai dengan segmentasi yang dituju.

Kedua, masalah permodalan. Permasalahan permodalan ini salah satunya disebabkan oleh permasalahan pemasaran. Sepinya jumlah pengunjung menyebabkan tingkat penghasilan para pedagang semakin berkurang,sehingga menyebabkan perputaran modal menjadi terhambat. Selain itu kurangnya manajemen keuangan dari para pedagang mengakibatkan para pedagang kesusahan dalam mengatur keuangannya. Sebagian besar para pedagang masih mencampuradukkan antara modal usaha dengan uang yang dipakai untuk kebutuhan pribadi.

Sesuai yang dikemukakan oleh Munawir, (2004) tersedianya kecukupan modal kerja dapat memberikan beberapa keuntungan yaitu melindungi perusahaan jika ada krisis dalam modal kerja yang disebabkan oleh turunnya nilai dari aktiva lancar, kemungkinan untuk bisa membayar semua kewajiban dengan tepat waktu, kemungkinan untuk memiliki persediaan dalam jumlah cukup untuk melayani para pelanggan, kemungkinan bagi perusahaan untuk memberikan syarat kredit yang sangat menarik untuk pelanggan, dan juga kemungkinan bagi perusahaan agar dapat berjalan dengan lebih efisien karena tidak memiliki kesulitan dalam memperoleh barang yang diinginkan.

Ketiga, masalah sarana dan prasarana. stan atau kios yang mereka gunakan untuk berjualan, ukurannya tidak sesuai dengan yang dijanjikan oleh pemerintah. Sehingga banyak pedagang yang kecewa dan mengeluhkan bahwa ukuran stan nya terlalu kecil sehingga susah untuk meletakkan dan menata barang dagangan yang akan dijual dengan baik. Adanya permasalahan ukuran stan yang kecil ini dikarenakan adanya kesalahan pendataan yang dilakukan oleh pengurus dan pemerintah.

Keempat, masalah kurangnya dukungan dari pemerintah. Dukungan yang dimaksud dalam hal ini adalah dukungan dalam bentuk bantuan dari pemerintah untuk mengatasi permasalahan yang dihadapi para pedagang. Jika pemerintah membantu para pedagang, misalnya bantuan dalam bentuk permodalan, maka para pedagang tidak akan mengalami kesulitan dalam perputaran permodalannya. Misalkan bantuan dalam permodalan ini, dengan memberikan kredit lunak terhadap para pedagang dan memberikan syarat yang mudah untuk memperoleh kredit lunak tersebut. Sehingga usaha yang dijalankan oleh mereka bisa berjalan dengan baik dan juga bisa meningkatkan pendapatan para pedagang.

Kelima, masalah teknologi. Permasalahan akses terhadap teknologi disebabkan karena kurangnya pengetahuan para pedagang dalam mengakses teknologi seperti internet dan sosial media sehingga masih kesulitan dalam memperluas pasar. Selain berpengaruh dalam hal pemasaran kurangnya akses terhadap teknologi juga berpengaruh dalam hal inovasi. Misalnya saja dalam hal model fashion terbaru yang selalu update setiap waktu.

\section{Upaya Yang Dilakukan Oleh Para Pedagang Dalam Mengatasi Permasalahan Yang Ada}

Pertama, upaya yang dilakukan para pedagang dalam mengatasi permasalahan pemasaran adalah dengan cara meningkatkan pelayanan dan bekerja sama dengan para pedagang dalam memasarkan barang dagangan. Cara yang digunakan pedagang untuk meningkan pelayanan adalah dengan memenuhi permintaan konsumen dan memberikan diskon khusus pada pembeli. Hal ini dilakukan agar pembeli yang membeli barang dagangan tersebut diharapkan akan menjadi pelanggan tetap para pedagang.

Kedua, upaya yang dilakukan para pedagang dalam mengatasi permasalahan permodalan adalah dengan cara berjualan di lokasi lain. Hal ini bertujuan agar para pedagang mendapatkan penghasilan tambahan demi mempertahankan usaha mereka. Dengan begitu perputaran modal usaha pedagang akan lebih lancar.

Ketiga, upaya yang dilakukan para pedagang dalam mengatasi permasalahan sempit nya ukuran stan adalah dengan cara mengatur letak barang dagangan dan mengurangi jenis dagangan.

Keempat, upaya yang dilakukan para pedagang dalam mengatasi permasalahan kurangnya dukungan dari pemerintah adalah dengan cara bekerja sama dengan pedagang yang lainnya. Walaupun tidak semua pedagang melakukan hal yang sama, namun upaya yang dilakukan cukup membantu untuk bisa mempertahankan usaha mereka.

Kelima, upaya yang dilakukan para pedagang dalam mengatasi permasalahan teknologi terutama akses dan pengetahuan terhadap penggunaan internet dan sosial media dalam memasarkan produk adalah dengan dibantu oleh anak atau para reseller yang paham dengan 
penggunaan internet dan sosial media untuk memasarkan produk dan mencari pelanggan baru.

Sedangkan upaya yang dilakukan oleh dinas terkait, dalam hal ini adalah DISPERINDAG dalam membantu mengatasi permasalahan yang dihadapi oleh para pedagang sesuai dengan yang diungkapkan oleh bapak Indro selaku Kepala bidang perdagangan DISPERINDAG kota Mojokerto dalam hal ukuran stan, pemerintah akan melakukan sidak kepada para pedagang yang melakukan pelanggaran yaitu dengan cara mengambil alih lagi stan yang telah diberikan jika pedagang tersebut tidak menggunakannya dengan selayaknya. Selain itu, dari sidak tersebut pemerintah akan melakukan normalisasi kembali ukuran stan menjadi 2x3 meter sesuai dengan ukuran awal.

Sesuai penelitian yang dilakukan oleh Haris (2011) bahwa hambatan yang dimiliki PKL adalah minimnya modal, sulitnya akses ke lokasi (pasar), dan kurangnya akses pada kebijakan pemerintah, informasi serta sarana ekonomi ataupun sosial. Strategi yang dikembangkan adalah berbentuk pemberdayaan seperti pemberian legalitas usaha dan permodalan, membangun komunikasi lebih dekat dengan para birokrat, pemberian bantuan sarana dan prasarana, dan juga pemberian pelatihan.

\section{PENUTUP}

\section{Simpulan}

Permasalahan pedagang kaki lima di Sentra PKL Jalan Benteng Pancasila Kota Mojokerto pasca relokasi adalah permasalahan pemasaran, permodalan, sarana dan prasarana dalam hal ini adalah sempit nya ukuran stan yang ditempati oleh para pedagang, serta kurangnya dukungan dari pemerintah dalam membantu mengatasi permasalahan yang ada. Selain itu, permasalahan lain yang ditemukan adalah mengenai teknologi yang meliputi pengetahuan dan pemanfaatan atau penggunaan internet serta media sosial dalam memasarkan produk.

Para pedagang kaki lima di Sentra PKL Jalan Benteng Pancasila Kota Mojokerto memiliki beberapa upaya dalam mengatasi permasalahan yang dihadapi antara lain dalam hal pemasaran yaitu mengganti jenis dagangan yang lebih menguntungkan, mencari pelanggan baru dengan cara memberi diskon, bekerja sama dengan para pedagang. Dalam hal permodalan upaya yang dilakukan adalah menggunakan uang tabungan pribadi, meminjam uang di bank dan teman, berjualan di lokasi lain. Selain itu, upaya yang dilakukan oleh pihak pemerintah atau DISPERINDAG kota Mojokerto terkait ukuran stand adalah melakukan sidak dan normalisasi ukuran stand. Meskipun tidak semua pedagang melakukan hal yang sama dalam mengatasi permasalahan yang ada, namun upaya yang dilakukan cukup membantu untuk bisa bertahan dalam usaha perdagangan mereka.

\section{Saran}

Dari simpulan di atas maka penulis mengajukan saran untuk kemajuan sentra PKL jalan Benteng Pancasila di kota Mojokerto. Adapun saran-saran yang penulis ajukan adalah (1) Bagi para pedagang diharapkan bisa membentuk koperasi. Sehingga permasalahan seperti permodalan bisa teatasi. (2) Bagi pemerintah diharapkan dapat membantu para pedagang dalam mengatasi permasalahan yang ada. Selain itu pemerintah perlu melakukan sosialisasi tentang penggunaan internet dan online shop selain kepada para pedagang juga kepada anggota keluarga yang nantinya akan menjadi penerus usaha mereka. (3) Bagi peneliti selanjutnya diharapkan bisa dijadikan acuan atau bahan referensi penelitian selanjutnya.

\section{DAFTAR PUSTAKA}

Burhan, B. (2015). Komunikasi Pariwisata Pemasaran dan Brand Destinasi. Jakarta: KENCANA Prenadamedia Group.

Haris, D. M. (2011). Strategi Pengembangan Usaha Sektor Informal Dalam Kemiskinan Di Perkotaan. Simposium Nasional Otonomi Daerah.

Munawir. (2004). Analisa Laporan Keuangan. Yogyakarta: Liberty.

Pribadi, F., \& Mundung, F. A. (2007). Manajemen Usaha UMKM. Malang: Bayumedia Publishing.

Sukirno, S. (2012). Pengantar Teori Makro Ekonomi. Jakarta: Rai Grafindo Persada.

Syamsir. (2011). Dampak Program Bantuan PKL Terhadap Tingkat Motivasi Pedagang Kaki Lima ( PKL ) di Provinsi Sumatera Barat. TINGKAP Vol. VII No. 1 Th. 2011, 8, 89-106.

Tambunan, T. (2003). Perekonomian Indonesia. Jakarta: Ghalia Indonesia. 